\title{
Epidemiological and ophthalmological findings in diabetic patients examined in a general hospital
}

\author{
Achados epidemiológicos e alterações oftalmológicas em \\ diabéticos atendidos em hospital geral secundário
}

Mariluce Silveira Vergara ${ }^{1}$, André Simoni de Jesus ${ }^{1}$, Lucia Campos Pellanda², Manuel A P Vilela ${ }^{2,3}$

\begin{abstract}
Objective: To evaluate the association between epidemiological and ophtalmological findings in diabetic patients. Methods: Crosssectional study. We selected consecutively diabetic patients examined during 2011 which responded to a questionnaire and examination. Results: The sample comprised 103 patients, of whom 72 (69.9\%) were female, 66 (64\%) were Caucasian, average age 59 (+/- 9,21) years, $64 \%$ reported minimum wages, $58.2 \%$ did not finish elementary school, $75.7 \%$ reported family history of diabetes, $45.6 \%$ reported regularly perform metabolic control, $54.3 \%$ did not receive special nutritional care. On examination, $72.8 \%$ had visual acuity of $20 / 40$. There was a significant association between retinal complications and insulin usage $(O R=8,3 ; p=0,003)$, and between low visual acuity and age $(O R=11,8 ; p=0,003)$ and insulin $(O R=5,48, p=0,021)$, as well with lower education and income. Conclusion: In this low-income and low-education population, glycemic control was poor, and related to the development of diabetic retinopathy and the consequent low vision. These findings emphasize the need to adopt broader strategies to improve control and prevention of diabetes mellitus.
\end{abstract}

Keywords: Diabetes mellitus; Diabetic retinopathy; Blindness

\section{Resumo}

Objetivo: Avaliar a associação entre alterações no exame oftalmológico, características epidemiológicas e controle metabólico em pacientes diabéticos. Métodos: Estudo transversal. Foram selecionados consecutivamante os diabéticos atendidos durante 2011 em um hospital secundário. Todos os pacientes responderam questionário e foram submetidos a exame oftalmológico. Resultados: Foram estudados 103 pacientes, dos quais 72 (69,9\%) eram do sexo feminino e 66 (64\%) da cor branca. A média de idade foi de 59 $(+/-9,21)$ anos. Sessenta e quatro por cento dos participantes referiram renda aproximada de até 1 salário mínimo, 58,2\% tinham ensino fundamental incompleto, 75,7\% com história de diabetes familiar, 45,6\% informaram realizar controle metabólico regular, $54,3 \%$ não observavam cuidados nutricionais, $28 \%$ usavam insulina, $99 \%$ eram diabéticos do tipo- 2 . Ao exame, $72,8 \%$ apresentaram acuidade visual corrigida de 20/40. Foram estatisticamente significativas as relações entre complicações retinianas e o uso de insulina $(\mathrm{OR}=8,3 ; \mathrm{p}=0,003)$ e da baixa acuidade visual com o uso de insulina $(\mathrm{OR}=5,48, \mathrm{p}=0,021)$ e a idade $(\mathrm{OR}=11,8 ; \mathrm{p}=0,003)$. Também foi observada relação entre a baixa de visão com escolaridade, idade e baixa renda Conclusão: Na população analisada, predominantemente de baixa renda e escolaridade, a condução inadequada da doença foi expressiva, o que se associou com a presença de complicações retinianas, reforçando a necessidade de adoção de medidas mais amplas para melhorar as estratégias de controle e prevenção do diabete mellitus.

Descritores: Diabetes mellitus; Retinopatia diabética; Cegueira

\footnotetext{
${ }^{1}$ Specialisation Course in Ophthalmology "Professor Ivo Correa-Meyer", Porto Alegre/RS, Brazil.

2 Post-Graduation Programme, Institute of Cardiology, Cardiology University Foundation; Federal University of Health Sciences of Porto Alegre (UFCSPA), Porto Alegre/RS, Brazil.

${ }^{3}$ Federal University of Pelotas, Pelotas/RS, Brazil.
}

Work conducted at the Institute of Cardiology of Viamão Hospital and the Federal University of Pelotas.

The authors declare no conflict of interest.

Received for publication 18/10/2012 - Acceped for publication 23/6/2014 


\section{INTRODUCTION}

A ccording to the World Health Organization, diabetes mellitus (DM) currently affects approximately 171 million people worldwide ${ }^{(1)}$. Of these, probably 10 to $20 \%$ have some form of retinopathy and about 1.78 million are blind. An estimated $7.7 \%$ of the population aged $20-70$ years (439 million) will have the disease by 2030 , of which $70 \%$ or more will be concentrated in developing countries ${ }^{(2)}$. This difference is based on factors such as population growth, ageing, inadequate diet, obesity, and sedentary lifestyle, in addition to reductions in the fasting glucose thresholds currently used for diagnosing $\mathrm{DM}^{(1-5)}$.

In Brazil, according to the Brazilian Diabetes Society ${ }^{(3)}$, the prevalence of DM in persons aged 30-69 years is 7.6\%; São Paulo, Porto Alegre and João Pessoa are the capitals with the highest prevalences.

Most diabetic patients, with rare exceptions ${ }^{(4)}$, do not undergo preventive ophthalmic examination with the recommended frequency and they ignore the consequences of the disease and the importance of prevention ${ }^{(5-13)}$. The most efficient method for evaluating the population utilises non-mydriatic cameras and specialised image-processing centres ${ }^{(14-33)}$.

The present study aimed to investigate the ophthalmic status of diabetic patients in the Brazilian public health system (SUS) in the city of Viamão, a municipality adjacent to Porto Alegre in the state of Rio Grande do Sul.

\section{Methods}

This study had an observational, cross-sectional design and it was approved by the Research Ethics Committee of the Institute of Cardiology of Viamão Hospital. Inclusion criteria were: diabetic patients covered by the SUS seen in 2011 at the ophthalmology outpatient clinic of the Institute of Cardiology of Viamão Hospital.

All diabetic patients seen at the clinic were invited to participate in the study. After providing their informed consent, they answered a questionnaire and underwent a complete ophthalmic examination.

The questionnaire included questions on sex, age, race, income, education, family history of diabetes, presence of other systemic diseases, a self-assessment of diabetes control (good, when following all the routine guidelines; moderate, in cases of partial adhesion; and bad, when the guidelines were not followed), diet (adhesion, supervision by a nutritionist), frequency of medical evaluations, knowledge of the potential consequences of diabetes, and frequency of fasting glucose testing (including tests with personal glucometers). Medical records were reviewed for information on glycosylated haemoglobin (last available result) and other non-ocular complications associated with diabetes.

All patients underwent an assessment of best corrected visual acuity (on a $\log$ MAR chart), intrinsic and extrinsic eye movements, applanation tonometry (Perkins), anterior slit lamp biomicroscopy, and binocular indirect ophthalmoscopy under mydriasis. Patients who did not fully provide their informed consent, answer the entire questionnaire, or undergo eye examination were excluded from the study.

Patients who had been fasting for more than 2 hours underwent capillary glucose testing (Accu-Chek Performa glucometer, Roche, Germany).

All the collected information was stored in a database using Microsoft Office Excel 2003 and analysed using Stata 12.1 software.
Table 1

Epidemiological characteristics of the study population

\begin{tabular}{llr}
\hline Variable & & $(\mathbf{9})$ \\
\hline Sex & Female & $(69,9)$ \\
Race & White & $(64)$ \\
& Black & $(26)$ \\
& Mixed-race & $(10)$ \\
Monthly family income & Up to the minimum wage & $(64)$ \\
& $>1$ and <3 times the minimum wage $(30)$ \\
& $>3$ times the minimum wage & $(6)$ \\
Education & Iliterate & $(18,5)$ \\
& Incomplete elemantary school & $(58)$ \\
& Elemantary school education & $(18,5)$ \\
Familiar kistory of DM & High school education or higher & $(5)$ \\
Type of diabetes & Yes & $(76)$ \\
Concomitant diseases & Type 2 & $(99)$ \\
& Systematic arterial hypertension & $(51)$ \\
& Ischemicheart disease & $(7)$ \\
& Acute myocardial infarction & $(9)$ \\
& Stroke & $(7)$ \\
Metabolic control & Renal failure & $(2)$ \\
& Good & $(39)$ \\
Treatment & Moderate & $(46)$ \\
Diet & Poor & $(15)$ \\
Supervision by a nutricionist & No & $(72)$ \\
Frequency of medical visit & Every 6 months & $(72)$ \\
& Every 3 months & $(48)$ \\
& Yearly & $(35)$ \\
& Once a week & $(17)$ \\
& Once a month & $(25,5)$ \\
& Quarterly & $(36,5)$ \\
& Never & $(31,5)$ \\
& Average & $(8,5)$ \\
& Oral hypoglycaemic agent & $(71)$ \\
& Oral hypoglycaemic agent + insulin & $(28)$ \\
& Insulin & $(1)$ \\
\hline & &
\end{tabular}

Table 2

Results of logistic regression for correlations between low visual acuity and other variables.

\begin{tabular}{lcccc}
\hline Low visual acuity & $\begin{array}{c}\text { Odds } \\
\text { ratio }\end{array}$ & $\begin{array}{c}\text { Standard } \\
\text { error }\end{array}$ & $\begin{array}{c}\mathbf{P} \\
\text { Value }\end{array}$ & {$[\mathbf{9 5 \%}$ CI] } \\
\hline Sex & 0,71 & 0,52 & 0,65 & $0,17-3,01$ \\
Race & 2,03 & 1,06 & 0,17 & $0,72-5,67$ \\
Income & 0,62 & 0,49 & 0,55 & $0,13-2,96$ \\
Education & 0,51 & 0,30 & 0,25 & $0,16-1,62$ \\
Family history & 0,40 & 0,30 & 0,23 & $0,92-1,77$ \\
Metabolic control & 0,74 & 0,32 & 0,5 & $0,31-1,75$ \\
General complications & 0,63 & 0,20 & 0,16 & $0,32-1,20$ \\
Blood glucose & 1,84 & 0,62 & 0,07 & $0,94-3,58$ \\
Insulin use & 5,48 & 4,03 & 0,02 & $1,3-23,2$ \\
Age & 11,8 & 9,94 & 0,003 & $2,26-61,5$ \\
Glycosylated haemoglobin & 1,23 & 1,01 & 0,8 & $0,24-6,16$ \\
Diet & 1,3 & 1,22 & 0,79 & $0,20-8,3$
\end{tabular}

[95\% CI $=95 \%$ Confidence interval ] 
Statistical analysis included a description through means and standard deviations or proportions, bivariate Pearson or Spearman correlations, and multivariate analysis (logistic regression). Results with $\mathrm{p}<0.05$ were considered statistically significant.

\section{Results}

The sample included 103 patients examined between March and December 2011. The mean age of respondents was $59.6(41-85)$ years. Most patients were white (64\%), followed by black $(26 \%)$ and mixed-race $(10 \%)$ patients. Table 1 shows the complete data.

On examination, visual acuity was equal to or better than $20 / 40$ in $73 \%$ of patients, and between $20 / 50$ and no light perception in $27 \%$. Fundus examination was normal in $53 \%$ of patients, non-proliferative diabetic retinopathy (DR) without macular oedema was found in $32 \%$, non-proliferative DR with macular oedema in $8 \%$, and high-risk proliferative DR in $6 \%$.

The glucometer test was performed on $60 \%$ of patients, with the following results: d" $200 \mathrm{mg} / \mathrm{dl}$ in $31 \% ; 201-300 \mathrm{mg} / \mathrm{dl}$ in $18 \% ; 301-400 \mathrm{mg} / \mathrm{dl}$ in $9 \%$; $401-500 \mathrm{mg} / \mathrm{dl}$ in $1 \%$; and e" $501 \mathrm{mg} / \mathrm{dl}$ in $1 \%$ (59\% had been fasting for more than 6 hours).

Logistic regression controlling for other variables found statistically-significant correlations between retinal complications and insulin use $(\mathrm{OR}=8.3, \mathrm{p}=0.003)$; low visual acuity and insulin use $(\mathrm{OR}=5.48, \mathrm{p}=0.021)$; and low visual acuity and age $(\mathrm{OR}=11.8$, $\mathrm{p}=0.003)$ (Table 2).

\section{Discussion}

In this study, the typical participant was a low-income, loweducation adult patient with type 2 diabetes using oral hypoglycaemic agents. Almost half of patients had retinopathy. Most patients underwent medical follow-up every three to six months but were unaware of the systemic diseases associated with diabetes and did not adhere adequately to medical recommendations.

Most patients had high capillary glucose levels, which were considered reliable as they were in agreement with glycosylated haemoglobin ${ }^{(34-36)}$. These results show that metabolic control was poor even though patients had access to specialist care.

Statistically-significant correlations were found between insulin use and retinopathy, low visual acuity and age, and low visual acuity and the need for insulin therapy. These findings reproduce the conditions of SUS patients in our region ${ }^{(6,7)}$ and are in agreement with most studies conducted in different locations ${ }^{(5-13,24-29)}$, which show that longer disease duration and greater difficulty controlling the disease (requiring insulin use) are associated with more severe ocular manifestations.

On average, $50-90 \%$ of diabetic patients are not evaluated under optimal conditions ${ }^{(1,2)}$. An exception to this is found in Peto and Tadros ${ }^{(4)}$, where $78 \%$ of diabetic patients over 15 years of age in the UK underwent retinal assessment with nonmydriatic cameras. Greater access to health care does not imply that all forms of treatment are available ${ }^{(37)}$, which can affect outcomes related to disease control ${ }^{(30-33)}$. In our environment, Guedes et al. ${ }^{(38)}$ studied a Family Health Programme and stressed the need to provide better treatment and education to diabetic patients, even though the authors used a small sample and had a high number of study drop-outs.

Reducing the incidence of blindness and its associated costs requires early detection and rigorous, universal, multidisciplinary, preventive specialist care. ${ }^{30-33}$ The main risk factors for RD are related to disease duration, metabolic control, the type of diabetes, and treatment (with a lower risk in patients treated with diet and a higher risk in insulin users), as well as other factors (genetic factors, systemic arterial hypertension, smoking, pregnancy, and nephropathy $)^{(24-29)}$. Considering that disease duration and the type of diabetes are related to $\mathrm{DR}^{(26-29)}$ and that a predominance of high-risk patients are found in our public health system, implementing targeted educational programmes and using nonmydriatic digital systems to acquire fundus images processed through telemedicine methods is required to reduce the incidence of blindness.

\section{Conclusion}

This study showed that essential elements in the management of RD in our health system, such as knowledge of the disease, periodic controls, nutritional support, and adherence to medical treatment, are still largely lacking. Patients with longer disease duration or requiring a greater number of drugs are very likely to suffer functional vision loss and severe retinal damage.

\section{References}

1. World Health Organization. Media centre. Diabetes. Fact sheet $\mathrm{N}^{\circ}$ 312. Updated March 2013. Available in: http://www.who.int/ mediacentre/factsheets/fs312/en/

2. Shaw JE, Sicree RA, Zimmet PZ. Global estimates of the prevalence of diabetes for 2010 and 2030. Diabetes Res Clin Pract. 2010;87(1):4-14.

3. Sociedade Brasileira de Diabetes [Internet]. [citado 2014 Jun12]. Disponível em: http://www.diabetes.org.br

4. Peto T, Tadros C. Screening for diabetic retinopathy and diabetic macular edema in the United Kingdom. Curr Diab Rep. 2012;12(4):338-45.

5. Nathan DM, Cleary PA, Backlund JY, Genuth SM, Lachin JM, Orchard TJ, Raskin P, Zinman B; Diabetes Control and Complications Trial/Epidemiology of Diabetes Interventions and Complications (DCCT/EDIC) Study Research Group). Intensive diabetes treatment and cardiovascular disease in patients with type 1 diabetes. N Engl J Med. 2005;353(25): 2643-53. Comment in N Engl $J$ Med. 2006; 354(16):1751-2; author reply 1751-2. ACP J Club. 2006; 144(3):63. N Engl J Med. 2005; 353(25):2707-9.

6. Vilela MA, Saadi AK, Pletsch L, Giacomet A. Inquérito entre pacientes e médicos sobre as estratégias aplicadas na prevenção e tratamento da retinopatia diabética. Arq Brasil Oftalmol. 1997;60(2):152-5.

7. Paiva LC, Costa JS, Jardim VM, Soares MC, D'Ávila AD. Avaliação da efetividade dos cuidados de saúde nos pacientes com diabetes mellitus em uma comunidade de Pelotas, RS: processo e resultado. Rev AMRIGS. 2004;48(1):5-10.

8. Friedman DS, Ali F, Kourgialis N. Diabetic retinopathy in the developing world: how to approach identifying and treating underserved populations. Am J Ophthalmol. 2011;151(2):192-4.e1.

9. Adriono G, Wang D, Octavianus C, Congdon N. Use of eye care services among diabetic patients in urban Indonesia. Arch Ophthalmol. 2011;129(7):930-5.

10. Trautner C, Haastert B, Giani G, Berger M. Incidence of blindness in southern Germany between 1990 and 1998. Diabetologia. 2001;44(2):147-50

11. Moreira ED Jr, Neves RC, Nunes ZO, de Almeida MC, Mendes $\mathrm{AB}$, Fittipaldi JA, Ablan F; Venezuelan Diabetes Investigators' Group. Glycemic control and its correlates in patients with diabetes in Venezuela: results from nationwide survey. Diabetes Res Clin Pract. 2010;87(3):407-14. 
12. McCarty CA, Lloyd-Smith CW, Lee SE, Livingston PM, Stanislavsky YL, Taylor HR. Use of eye care services by people with diabetes: the Melbourne Visual Impairment Project. Br J Ophthalmol. 1998;82(4):410-4. Erratum in Br J Ophthalmol. 1998;82(5):591.

13. Minassian DC, Owens DR, Reidy A. Prevalence of diabetic macular oedema and related health and social care resource use in England. Br J Ophthalmol. 2012;96(3):345-9.

14. Andonegui J, Serrano L, Eguzkiza A, Berástegui L, JiménezLasanta L, Aliseda D, et al. Diabetic retinopathy screening using tele-ophthalmology in a primary care setting. J Telemed Telecare. 2010;16(8):429-32.

15. Levy J, Lifshitz T, Goldfarb D, Knyazer B, Belfair N. Screening for diabetic retinopathy with a mobile non-mydriatic digital fundus camera in southern Israel. Isr Med Assoc J. 2011;13(3):137-40.

16. Tarabishy AB, Campbell JP, Misra-Hebert A, Seballos RJ, Lang RS, Singh RP. Non-mydriatic single-field fundus photography for the screening of retinal diseases in an executive health clinic. Ophthalmic Surg Lasers Imaging. 2011;42(3):102-6.

17. García Serrano MJ,Asensi Blanch A,Farré Marimon JM, Colomé Sabaté I, Gras Miguel M, Saldias Ochandonera Q, et al. [User satisfaction with teleophthalmology with nonmydriatic camera for diabetic retinopathy screening]. Gac Sanit. 2009;23(4):322-5. Spanish.

18. Mash B, Powell D, du Plessis F, van Vuuren U,Michalowska M, Levitt N. Screening for diabetic retinopathy in primary care with a mobile fundal camera-evaluation of a South African pilot project. S Afr Med J. 2007;97(12):1284-8.

19. Lopez-Bastida J, Cabrera-Lopez F, Serrano-Aguilar P. Sensitivity and specificity of digital retinal imaging for screening diabetic retinopathy. Diabet Med. 2007;24(4):403-7.

20. Neubauer AS, Rothschuh A, Ulbig MW, Blum M. Digital fundus image grading with the non-mydriatic Visucam(PRO NM) versus the FF450(plus) camera in diabetic retinopathy. Acta Ophthalmol. 2008;86(2):177-82.

21. Baeza M, Orozco-Beltrán D, Gil-Guillen VF, Pedrera V, Ribera $\mathrm{MC}$, Pertusa S, et al. Screening for sight threatening diabetic retinopathy using non-mydriatic retinal camera in a primary care setting: to dilate or not to dilate? Int J Clin Pract. 2009;63(3):433-8.

22. Lin DY, Blumenkranz MS, Brothers RJ, Grosvenor DM. The sensitivity and specificity of single-field nonmydriatic monochromatic digital fundus photography with remote image interpretation for diabetic retinopathy screening: a comparison with ophthalmoscopy and standardized mydriatic color photography. Am J Ophthalmol. 2002;134(2):204-13. Comment in Am J Ophthalmol. 2002;134(2):261-3.

23. Romero P, Sagarra R, Ferrer J, Fernández-Ballart J, Baget M. The incorporation of family physicians in the assessment of diabetic retinopathy by non-mydriatic fundus camera. Diabetes Res Clin Pract. 2010;88(2):184-8.

24. Porta M, Tomalino MG, Santoro F, Ghigo LD, Cairo M,Aimone M, et al. Diabetic retinopathy as a cause of blindness in the province of Turin, north-west Italy, in 1967-1991. Diab Med. 1995;12(4):355-61.

25. Sriwijitkamol A, Moungngern Y, Vannaseang S. Assessment and prevalences of diabetic complications in 722 Thai type 2 diabetes patients. J Med Assoc Thai. 2011;94 Suppl 1:S168-74.

26. UK Prospective Diabetes Study (UKPDS). VIII. Study design, progress and performance. Diabetologia. 1991;34(12):877-90.

27. The effect of intensive treatment of diabetes on the development and progression of long-term complications in insulin-dependent diabetes mellitus. The Diabetes Control and Complications Trial Research Group. N Engl J Med. 1993;329(14):977-86. Comment in ACP J Club. 1994;120 Suppl 2:30-1. N Engl J Med. 1994; 330(9):641; author reply 642. N Engl J Med. 2006; 354(16):1751-2; author reply 1751-2. N Engl J Med. 1993;329(14):1035-6.
28. ACCORD Study Group; ACCORD Eye Study Group, Chew EY, Ambrosius WT, Davis MD, Danis RP, Gangaputra S, Greven CM, et al. Effects of medical therapies on retinopathy progression in type 2 diabetes. N Engl J Med. 2010;363(3):233-44. Erratum in N Engl J Med. 2011;364(2):190. N Engl J Med. 2012;367(25):2458. Comment in N Engl J Med.2010;363(3):287-8. Epub 2010 Jun 29. N Engl J Med. 2010;363(22):2171; author reply 2173-4. N Engl J Med. 2010;363(22):2172; author reply 2173-4. N Engl J Med. 2011;364(2):188-9. Evid Based Med.2011;16(2):45-6. Ann Intern Med. 2010;153(10):JC5-10.

29. Klein R, Klein BE, Moss SE, Cruickshanks KJ. The Wiscosin Epidemiologic Study of Diabetic Retinopathy: XVII. The 14-year incidence and progression of diabetic retinopathy and associated risk factors in type I diabetes. Ophthalmology. 1998;105(10):1801-15. Comment in Ophthalmology. 1998;105(10):1799-800.

30. Hörnsten A, Stenlund H, Lundman B, Sandström H. Improvements in $\mathrm{HbA} 1 \mathrm{c}$ remain after 5 years - a follow up of an educational intervention focusing on patients' personal understandings of type 2 diabetes. Diabetes Res Clin Pract. 2008;81(1):50-5.

31. Song M, Ratcliffe SJ, Tkacs NC, Riegel B. Self-care and health outcomes in diabetes mellitus. Clin Nurs Res. 2012;21(3):309-26.

32. Murphy HR, Wadham C, Hassler-Hurst J, Rayman G, Skinner TC; Families and Adolescents Communication and Teamwork Study (FACTS) Group. Randomized trial of a diabetes self-management education and family teamwork intervention in adolescents with Type-1 diabetes. Diabet Med. 2012;29(8):e249-54.

33. Rautio N, Jokelainem J, Oksa H, Saaristo T, Peltonen M, Niskanen L, et al. Participation, socioeconomic status and group or individual counselling intervention in individuals at high risk for type 2 diabetes: one-year follow-up study of the FIN-D2D-project. Prim Care Diabetes. 2012;6(4):277-83.

34. Bergenstal RM. Evaluating the accuracy of modern glucose meters. Insulin. 2008;3(1):5-14.

35. Francescato MP, Geat M, Stel G, Cauci S. Accuracy of portable glucose meter and of a Continuous Glucose Monitoring device used at home by patients with type 1 diabetes. Clin Chim Acta. 2012;18;413(12):312-8

36. Solnica B, Naskalski JW, Sieradzki J. Analytical performance of glucometers used for routine glucose self-monitoring of diabetic patients. Clin Chim Acta. 2003;331(1-2):29-35.

37. Paniz VM, Fassa AG, Facchini LA, Piccini RX, Tomasi E, Thumé E, et al. Free access to hypertension and diabetes medicines among the elderly: a reality yet to be constructed. Cad Saúde Pública. 2010;26(6):1163-74.

38. Guedes MF, Portes AJ, Couto Júnior AS, Nunes JS, Oliveira RCl. Prevalência da retinopatia diabética em unidade de Programa de Saúde da Família. Rev Bras Oftalmol. 2009;68(2):90-5.

\section{Corresponding author:}

Manuel A. P. Vilela

Rua Félix da Cunha, 496

CEP 90570-000 - Porto Alegre/RS, Brazil

E-mail: vilela@vilelaoftalmologia.com.br 